\title{
西
}

\section{Participation of Rural Residents Implementation of Infrastructure Development Criteria in New Rural Construction in Vietnam}

\author{
Tran Thi Thoa \\ National Academy of Public Administration
}

\begin{abstract}
The role of the residents has been proved through many activities of social life. Since the implementation of the national target program on new rural construction, thanks to active participation from the people, our country has experienced significant changes, the production and living conditions of the people have been increasingly renewed. Modern rural infrastructure gradually plays an important role in improving the quality of life and promoting socio-economic development in rural areas. In the process of implementing new rural construction, rural residents are becoming more and more aware of their own social responsibility for rural infrastructure development. Therefore, this article focuses on research some theoretical issues participation and practicality of participation of rural residents to implement criteria for rural infrastructure development promote their participation to implement infrastructure development criteria in the process of building new rural areas in Vietnam.
\end{abstract}

Keywords: participation, rural residents, new rural

\section{INTRODUCTION}

In the theory of community development, the beginning of people's participation appeared from the early 1940s in the first British colonies from very simple initiatives to help people improve their lives. The actual implementation process has brought about significant efficiency when there is a positive contribution of local people to improve their own lives.

Afterwards, Arnstein 1969 presented the fundamental theory of people's ladder of participation. Since then, studies of community participation have become more and more popular and studied in many different areas. Chadwick (1971) argues that participation in decision making, the public will recognize the importance of their participate in deciding their future (Marzuki, 2015, p. 21). Participation means that people are closely involved in economic, social, cultural and political processes that affect their lives (UNDP, 1993, p. 21). Participation is broader, including: participation in policy making and decision making in important areas affects their lives (Gaventa \& Valderrama, 1999, p. 4). The participation of local people and other stakeholders in the creation, implement content and conduct a program or policy designed to change their lives (Jenning, 2000, p. 1). Participation can be expressed in terms of: resource contribution; management and coordination efforts; participation in the program (Zomorrodian et al., 2013, p. 318). 
National Targeted Programs for New Rural construction in Vietnam to implement the Central Executive Committee Resolution 26 on August 5, 2008 and the Action Program of the Government on develop comprehensively and comprehensively economic, political, sociocultural and ecological environment in rural areas. The new rural construction program in Vietnam refers to 5 issues that need to be done in rural areas in Vietnam: planning, rural infrastructure, rural economy, culture - society - environment and the political system in rural areas. After 8 years of development, the role of the rural residents is emphasized, especially the positive of rural residents in implementing rural infrastructure development criteria. At many localities, rural residents actively discussed and co-opted with the Government to decide on infrastructure development plans to implement infrastructure criteria in new rural construction...

Therefore, studying the participation of rural residents in implementing the criteria of infrastructure development in new rural construction in Vietnam plays an important role to explore the relationship between the participation of rural residents with the results of implementing infrastructure criteria in new rural construction to promote the role of the rural residents in implementing the national target program on new rural construction in Vietnam.

\section{RESEARCH OVERVIEW}

Rural infrastructure is an important condition for the developing rural economic, improving the quality of life of the people, is the basis for rural modernization. Rural infrastructure is the first factor to encourage and attract economic activities to rural areas. The role of rural residents in the development, use and protection rural infrastructure was proved by World Bank (1994) through the participation of rural residents in developing infrastructure in Africa, Asia, Nepal, Latin America and Malaysia. Research has shown that using more community resources will be more sustainable efficiency, following that there are three key reasons for efficiency: participation of direct beneficiaries; looking for the initial consensus of direct beneficiaries and mobilizing cash or contribute in kind. After that, Laah's research (2013) continues to assess the extent of the participation of rural people in maintaining rural infrastructure, assess the impact of communities involved in developing sustainable infrastructure, evaluating the challenges to join the infrastructure development community in the context of the Riyom region - Nigeria's plateau. With other arguments, Gabriel's research (2015) make two hypotheses: "Government interventions in Ogoniland have no significant impact on basic infrastructure in Ogoniland; the interventions of Ogoniland oil companies impact on basic infrastructure in Ogoniland do not have much. " to proving that the role of rural residents is important for developing sustainable rural infrastructure, according to the author's study, rural households can contribute significantly to infrastructure development plans in their communities. Research works of Nurlaila and colleagues (2015) on the basis of identifying public participation in developing village energy with the behaviour changes of local communities and analyzing the actual implementation of village programs, self-sufficiency energy to recommend energy policy to stimulate local community contributes to developing rural infrastructure in general and energy infrastructure in particular. In Vietnam, contributing opinions, contributing labor, rural people have been very enthusiastic to participating and be awaring the ownership and ownership of infrastructure works, thereby providing better efficiency with the maintenance and regular maintenance of works (3rd quarter ISG Newsletter in 2016).

\section{RESEARCH METHODOLOGY}

The first concept used in this study is: The results of implementing the criteria of infrastructure in new rural construction in Vietnam with the targets achieved are adequate rural infrastructure, synchronous and convenient, serving better the demands of social life in rural 
areas, rural residents' satisfaction on rural infrastructure. The second concept is the participation of rural residents to implement the criteria of infrastructure in new rural construction in Vietnam, which is understood as the fact that rural residents have to perform specific tasks in the development process and benefit from such activities. Rural residents need to take an active social responsibility in grasping information and giving opinions, participate in the decision-making process, make decisions and they are beneficiaries of the benefits of the new rural construction program.

The participation of rural residents is reflected in the fact that they are allowed to attend meetings, explained and provided with sufficient information about programs and projects (Hourdequin, 2012, p. 38). Participation of rural residents in the comments on the plan (planning scheme, list of works, etc), discussion, decision on contribution level, work performance (Finsterbusch, 1987, p. 10). The participation of rural residents is demonstrated by exercising the right to monitor the organization process, implementing infrastructure criteria for new rural construction (Conrad, 2011, p. 283; Danielsen, 2009, p. 39).

Research using quantitative method by direct interview and taking questionnaires for rural households in communes that have completed the national target program on new rural construction in the 2010 period - 2018, through the application of the scale of previous studies on participation of people in community development, in rural development, the author hypothesizes that research is the participation of rural farmers has a relationship with the results of implementing infrastructure criteria, specifically:...

Hypothesis: The participation of rural residents has a positive impact on the results of implementing infrastructure development criteria in new rural construction.

Research using convenient samples was interview and collected questionnaires of 300 households living in new rural communes. The survey questionnaire consisted of 6 independent factors (the scale of participation to the results of new rural construction) with 17 observed variables evaluated by 5 levels according to Likert scale.

Based on familiar relationships, the author directly distributed 400 votes in 5 newly recognized rural communes in 4 different provinces (Hanoi, Quang Ninh, Thai Binh, Ninh Binh). Filtering less than 100 unsatisfactory responses, 300 valid votes are used for data analysis. Steps to analyze data include: testing the reliability of scale by Cronbach Alpha method, factor analysis to draw potential factors from a set of smaller observed variables and single multivariate regression analysis to test research hypotheses.

\section{RESULT}

The Cronbach alpha method is used to evaluate the reliability of the scale, the results of running Cronbach alpha scales of reliability requirements. Specifically, the participation of rural residents measured by 6 scales with Cronbach alpha is greater than 0.6, indicating that these scales ensure good quality.

Next, the exploratory factor analysis (EFA) method used to evaluate the convergence and discrimination value of the scale, the implementation of EFA shows that $\mathrm{KMO}=0.617$, satisfying the condition of $0.5<\mathrm{KMO}<1$, factor analysis is appropriate for actual data (Table 1 ). 
Table 1. Testing of KMO and Bartlett

KMO and Bartlett's Test

\begin{tabular}{|lc|c|}
\hline Kaiser-Meyer-Olkin Measure of Sampling Adequacy. & .617 \\
& Approx. Chi-Square & 1664.727 \\
Bartlett's Test of Sphericity & $\mathrm{df}$ & 136 \\
& Sig. & .000 \\
\hline
\end{tabular}

The variance method is $70.7 \%$ at the eigen-value of 1,119 and the measurement variables are highly weighted (> 0.55) on the concepts they measure, low on the concept they are not measured. Therefore, the scale of the concept of the above research has achieved convergence and discrimination value (Table 2, Table 3).

Table 2. Total variance extracted explained

Total Variance Explained

\begin{tabular}{|c|c|c|c|c|c|c|c|c|c|}
\hline \multirow{2}{*}{$\begin{array}{c}\text { Com } \\
\text { pone } \\
\text { nt }\end{array}$} & \multicolumn{3}{|c|}{ Initial Eigenvalues } & \multicolumn{3}{|c|}{$\begin{array}{l}\text { Extraction Sums of Squared } \\
\text { Loadings }\end{array}$} & \multicolumn{3}{|c|}{$\begin{array}{c}\text { Rotation Sums of Squared } \\
\text { Loadings }\end{array}$} \\
\hline & Total & \begin{tabular}{|c|}
$\%$ of \\
Variance \\
\end{tabular} & $\begin{array}{c}\text { Cumulative } \\
\%\end{array}$ & Total & $\begin{array}{c}\% \text { of } \\
\text { Variance }\end{array}$ & $\begin{array}{c}\text { Cumulativ } \\
\mathrm{e} \%\end{array}$ & Total & $\begin{array}{c}\% \text { of } \\
\text { Variance }\end{array}$ & \begin{tabular}{|c} 
Cumulati \\
ve $\%$
\end{tabular} \\
\hline 1 & 2.741 & 16.125 & 16.125 & 2.741 & 16.125 & 16.125 & 2.354 & 13.847 & 13.847 \\
\hline 2 & 2.557 & 15.038 & 31.163 & 2.557 & 15.038 & 31.163 & 2.168 & 12.750 & 26.597 \\
\hline 3 & 2.201 & 12.946 & 44.109 & 2.201 & 12.946 & 44.109 & 2.054 & 12.083 & 38.680 \\
\hline 4 & 1.755 & 10.322 & 54.431 & 1.755 & 10.322 & 54.431 & 1.898 & 11.167 & 49.847 \\
\hline 5 & 1.648 & 9.693 & 64.124 & 1.648 & 9.693 & 64.124 & 1.848 & 10.873 & 60.720 \\
\hline 6 & 1.119 & 6.581 & 70.704 & 1.119 & 6.581 & 70.704 & 1.697 & 9.985 & 70.704 \\
\hline 7 & .777 & 4.569 & 75.273 & & & & & & \\
\hline 8 & 660 & 3.880 & 79.153 & & & & & & \\
\hline 9 & .633 & 3.725 & 82.878 & & & & & & \\
\hline 10 & .504 & 2.967 & 85.845 & & & & & & \\
\hline 11 & .469 & 2.756 & 88.601 & & & & & & \\
\hline 12 & .430 & 2.529 & 91.130 & & & & & & \\
\hline 13 & .378 & 2.226 & 93.357 & & & & & & \\
\hline 14 & .358 & 2.104 & 95.461 & & & & & & \\
\hline 15 & .330 & 1.940 & 97.401 & & & & & & \\
\hline 16 & .274 & 1.614 & 99.014 & & & & & & \\
\hline 17 & 168 & .986 & 100.000 & & & & & & \\
\hline
\end{tabular}

Extraction Method: Principal Component Analysis. 
Table 3. Factor Rotations Matrix

Rotated Component Matrix ${ }^{a}$

\begin{tabular}{|c|c|c|c|c|c|c|}
\hline & \multicolumn{6}{|c|}{ Component } \\
\hline & 1 & 2 & 3 & 4 & 5 & 6 \\
\hline TN1 & & .824 & & & & \\
\hline TN2 & & .813 & & & & \\
\hline TN3 & & .863 & & & & \\
\hline YK1 & .746 & & & & & \\
\hline YK2 & .910 & & & & & \\
\hline YK3 & .831 & & & & & \\
\hline DG1 & & & & & .846 & \\
\hline DG2 & & & & & .806 & \\
\hline DG3 & & & & & .580 & \\
\hline GS1 & & & .797 & & & \\
\hline GS2 & & & .856 & & & \\
\hline GS3 & & & .750 & & & \\
\hline CQ1 & & & & .805 & & \\
\hline CQ2 & & & & .844 & & \\
\hline SD1 & & & & & & .841 \\
\hline SD2 & & & & & & .858 \\
\hline
\end{tabular}

Extraction Method: Principal Component Analysis.

Rotation Method: Varimax with Kaiser Normalization.

a. Rotation converged in 6 iterations.

So, after verifying the quality of the scale and EFA tests, identify 6 scales representing the participation of rural residents and 1 scale for the implementation of infrastructure criteria in construction new rural with 20 typical variables (Table 4).

Table 4: Model adjustment for cronbach Alpha and exploratory factor analysis

\begin{tabular}{|c|c|c|l|}
\hline No & Scale & Variable characteristic & \multicolumn{1}{|c|}{ Explain } \\
\hline 1 & YK (F1) & YK1, YK2, YK3 & Discussed and contributed ideas \\
\hline 2 & TN (F2) & TN1, TN2, TN3 & Received information \\
\hline 3 & GS (F3) & GS1, GS2, GS3 & $\begin{array}{l}\text { Monitoring during the implementation of } \\
\text { infrastructure criteria }\end{array}$ \\
\hline 4 & DG (F4) & DG1, DG2, DG3 & Participate in material contributions \\
\hline 5 & CQ (F5) & CQ1, CQ2 & Participate in upgrading and creating landscapes \\
\hline 6 & SD (F6) & SD1, SD2 & Use and protection of works \\
\hline 7 & KQ & KQ1, KQ2, KQ3, KQ4 & $\begin{array}{l}\text { Results of implementation of infrastructure } \\
\text { development criteria }\end{array}$ \\
\hline
\end{tabular}


To consider which scale of participation affects the performance of infrastructure criteria in new rural construction will be implemented by linear regression equation:

$\mathrm{KQ}=\mathrm{b} 0+\mathrm{b} 1 \mathrm{~F} 1+\mathrm{b} 2 \mathrm{~F} 2+\mathrm{b} 3 \mathrm{~F} 3+\mathrm{b} 4 \mathrm{~F} 4+\mathrm{b} 5 \mathrm{~F} 5+\mathrm{b} 6 \mathrm{~F} 6+\mathrm{ei}$

The variables included in the regression analysis are determined by calculating the points of the factors. The regression results show that all variables have Sig smaller than 0.01 , indicating that F1, F2, F3, F4, F5, F6 correlate significantly with KQ (results of implementing infrastructure development criteria in new rural construction). Durbin Watson is 1,673 so there is no superlative string correlation in the model. R2 calibrated as 0.307 means that $30.7 \%$ of changes in the results of implementing infrastructure development criteria in new rural construction are explained by independent variables of rural residents' participation. This is completely true to the reality of implementing the criteria of infrastructure development of rural residents with the results of rural infrastructure criteria achieved in the past time.

\section{CONCLUSIONS AND DISCUSSION}

This study examines the relationship between the participation of rural residents and the results of implementing infrastructure development criteria in new rural construction.

Theoretically, this study answers the question of how is the involvement of rural residents affected to implement the criteria of infrastructure development in new rural construction in Vietnam?.

In practical terms, the results of this study discuss the responsibility of rural residents to participate in rural infrastructure development work, discussing the role of the rural residents in taking appropriate measures, help to effective use local resources and promote the highest participation of rural residents to implement the criteria of infrastructure development in new rural construction. There are 16 scales tested in practice, the participation of rural residents to implement of infrastructure development criteria and 4 measurement scales on the results of implementing the criteria for infrastructure development in new rural construction.

Previous studies have assessed the level of participation of rural residents in rural infrastructure development and examined the impact of community participation on the sustainability of rural infrastructure (Laah, Adefila, Yusuf) 2013; Gabriel, 2015). This study applies the theory of participation, the participation of rural residents in rural development and the practice of participation of rural residents in rural infrastructure development to continue verifying and proposing the relationship between the participation of rural residents and the results of implementing infrastructure criteria in new rural construction in Vietnam. The article discusses the content of rural residents to implement the criteria of infrastructure created by localities in promoting the role of the subject of rural residents to create high consensus and effectively mobilize resources at places like: rural residents actively carry out works on infrastructure development, are willing to donate land and exchange land for the construction of public works (expanding roads, schools, irrigation, clean water supply works, clinics, ...); renovate, repair and upgrade the works of the family and villages more spacious and clean.

However, in order to participation of rural residents to be applied to the implementation of infrastructure criteria in new rural construction, the Government at all levels should facilitate rural residents in the direction of:

First, create a real democratic mechanism in all the work of the process of implementing rural infrastructure criteria so that rural residents know and participate. Consultation and publicity will create a mechanism for people to exercise their mastery and promote community responsibility so that rural residents can contribute practically to the locality. 
Second, should have a mechanism to promote the internal resources of the local community. The Government needs to effectively implement the key role of policy mechanisms as a motivation for localities and communities to plan their work related to their interests.

Third, create conditions to improve the capacity of rural residents to participate through the methods of improving intellectual standards, means and science and technology to support the community to participate in specific tasks of the process of implementing criteria for rural infrastructure development;

Fourth, reducing the Government's public investment in rural infrastructure to eliminate the need to rely on the Government's investment and create a mechanism for farmers to be forced to have the responsibility to rise to develop family economic

Fifth, having a strict monitoring mechanism for accountability, decentralize to local communities and communities according to the provisions of law helping them implement better the mobilization of resources and transparency of all activities in new rural construction

\section{REFERENCES}

Arnstein, S. R (1969), 'A ladder of citizen participation', Journal of the American Institute of Planners, 35(4), pp. 216 - 224.

Conrad, Danielsen, F và cộng sự. (2009). 'Local Participation in Natural Resource Monitoring: A Characterization of Approaches', Conservation Biology, 23 (1), 31-42.

Jenning, R. (2000). 'Participatory Development as New Paradigm: The Transition of Development Professionalism', Community Based Reintegration and Rehabilitation in Post-Conflict Settings Conference Washington, DC, USA, October 2000.

Gabriel, M. O., Emmanuel, N., Josiah, O. A \& Nnaemeka, I. I. (2015). 'Assessing Infrastructural Development in Ogoniland in the Niger Delta Region of Nigeria: A Participatory Development Approach', International Journal of Academic Research in Business and Social Sciences, 5 (12), 354-365.

Gaventa, J \& Valderrama, C. (1999). 'Participation, Citizenship and Local Governance', Background note prepared for workshop on Strengthening participation in local governance. Brighton, UK: Institute of Development Studies, pp. 02.

Laah, D. E., Adefila, O. J \& Yusuf, O. R. (2013). 'Community Participation in Sustainable Rural Infrastructural Development in Riyom Area, Plateau State of Nigeria', Journal of Economics and Sustainable Development, 4, 19.

Marzuki, A. (2015). 'Challenges in the Public Participation and the Decision Making Process', Sociologija I Prostor, 201 (1): pp. 21-39, https://pdfs.semanticscholar.org.

Nurlaila. I, Yuliar. S, Kombaitanb. B and Madyo. E. A (2015), 'Public Participation: Energy policy aspect to support rural electrification program in West Java', Procedia - Social and Behavioral Sciences, 168, 321-327

UNDP (1993). "Human Development Report." New York Oxford: p. 21.

World Bank (1994), World Development Report 1994, Infrastructure for development, Oxford University Press.

Zomorrodian, A. H., Gill, S. S., Samaha, A. A., \& Ahmad, N. (2013). 'Quantitative Models for Participation Evaluation in Community Development: A Theoretical Review' World Applied Sciences Journal 25(2), 314-322. 